\title{
The possibilities of independent functioning in the opinion of patients with cerebral palsy on the threshold of adulthood - preliminary study
}

\section{Możliwości samodzielnego funkcjonowania w opinii pacjentów z mózgowym porażeniem dziecięcym u progu dorosłości - badanie wstępne}

\author{
Jolanta Taczała1 (iD, Magdalena Dmoszyńska-Graniczka² (D), Marek Cybulski² (D), Piotr Majcher ${ }^{1}$ (D), \\ Magdalena Chrościńska-Krawczyk ${ }^{3}$ (D), Michał Latalski (iD)
}

\begin{abstract}
${ }^{1}$ Department of Rehabilitation, Physiotherapy and Balneotherapy, Medical University of Lublin, Magnoliowa 2, 20-143 Lublin, Poland
2 Department of Biochemistry and Molecular Biology, Medical University of Lublin, Chodźki 1, 20-093 Lublin, Poland

${ }^{3}$ Department of Pediatric Neurology, Medical University of Lublin, Gębali 6, 20-093 Lublin, Poland

${ }^{4}$ Department of Pediatric Orthopedics, Medical University of Lublin, Gębali 6, 20-093 Lublin, Poland
\end{abstract}

DOI:10.20966/chn.2018.58.417

\section{ABSTRACT}

Background: According to the International Classification of Functioning, Disability and Health, the rehabilitation of patients with cerebral palsy should be aimed at achieving the maximum level of functioning. It is extremely important to know the opinions of the patients regarding their needs and expectations.

Objective: The aim of the study was to identify and present the opinions of cerebral palsy patients on the possibility of independent functioning in adulthood within the context of their functional assessment. Materials and methods: The study included 29 people aged between 15 and 18. Functional assessments were performed using scales describing mobility, hand functions and communication. In addition, a questionnaire and a patient survey card were used. Results: More than half of the surveyed patients $(55.2 \%)$ plan to live independently. A negative correlation between The Gross Motor Function Classification System (GMFCS) level and adult independence was observed. Only $34.5 \%$ of patients with cerebral palsy report disability as a cause of interpersonal problems. The most common obstacles to independent living were mobility difficulties $(41.4 \%)$, job-finding problems $(24.1 \%)$, and lack of accessibility (20.7\%). Conclusions: The level of functioning of patients with $\mathrm{CP}$ affects their perception of independent living. Patients classified at a GMFCS level I and II and patients with hemiplegia are more likely to achieve independence in adulthood than those classified at a GMFCS level IV and V or those with diplegia and tetraplegia.

Key words: cerebral palsy, independence, functional assessment

\section{STRESZCZENIE}

Wstęp: Zgodnie z koncepcją Międzynarodowej Klasyfikacji Funkcjonowania, Niepełnosprawności i Zdrowia rehabilitacja osób z mózgowym porażeniem dziecięcym powinna być ukierunkowana na osiagnięcie maksymalnego poziomu funkcjonowania. Niezwykle ważne jest poznanie opinii samych pacjentów na temat ich potrzeb i oczekiwań. Cel pracy: Poznanie i przedstawienie opinii pacjentów z MPD dotyczących możliwości samodzielnego funkcjonowania w dorosłym życiu w kontekście ich oceny funkcjonalnej. Materiał i metody: Grupę badaną stanowiła młodzież w wieku 15-18 lat - 29 osób. Za pomocą skal opisujących możliwości poruszania się, funkcji rąk i komunikacji (GMFCS, MASC, CFCS) dokonano oceny funkcjonalnej. Ponadto posłużono się kwestionariuszem ankiety i kartą badania pacjenta. Wyniki badań: Ponad połowa badanych pacjentów $(55,2 \%)$ wyobraża sobie egzystencję bez pomocy drugiej osoby. Stwierdzono ujemną korelację pomiędzy stopniem GMFCS a samodzielnością w dorosłym życiu. Tylko 34,5\% pacjentów z MPD, jako przyczynę problemów w kontaktach z rówieśnikami podaje niepełnosprawność. Wśród przeszkód na drodze do samodzielnego życia, najczęściej chorzy wymieniali trudności w poruszaniu się $(41,4 \%)$, problem ze znalezieniem pracy $(24,1 \%)$, czy wreszcie bariery architektoniczne $(20,7 \%)$. Wnioski: Poziom funkcjonowania pacjentów z MPD wpływa na ich wyobrażenie samodzielnego życia. Chorzy z poziomem funkcjonalnym GMFCS I i Il oraz chorzy $\mathrm{z}$ hemiplegią łatwiej osiągają niezależność $\mathrm{w}$ dorosłym życiu niż chorzy z poziomem funkcjonalnym GMFCS IV i V oraz z di- czy tetraplegią.

Słowa kluczowe: mózgowe porażenie dziecięce, samodzielność, ocena funkcjonalna

\section{INTRODUCTION}

According to the International Classification of Functioning, Disability and Health (ICF), the rehabilitation of patients with cerebral palsy (CP) should be aimed at achieving the maximum level of functioning in daily life and the fullest possible participation in society $[1,2]$. It is difficult to predict the development of a child whose diagnosis of
$\mathrm{CP}$ was made in infancy. Cerebral palsy describes a group of non-progressive, but often changing, motor dysfunction secondary to early brain changes. Movement disorders in $\mathrm{CP}$ may be accompanied by convulsions/epilepsy, sensory or cognitive function disturbances or dysfunctions in communication, perception and behavior $[3,4]$. 
In recent years a few scales of functional assessment have been developed for children with cerebral palsy regarding the gross motor functions - the Gross Moto Functional Classification System (GMFCS), for the assessment of the small motor skills - the Manual Ability Classification System (MACS) and the Communication Function Classification System (CFCS) for the evaluation of everyday communication performance. Developed in 2006 the GMFCS functional scale describes possibilities and patterns of movement based on self-initiated movement abilities of CP patients. Depending on the motor skills, children are qualified into one of five levels. Children functioning at level I walk without limitations and can climb stairs without the use of a railing. Children at level II climb stairs holding onto a railing and may need help when walking on an uneven terrain. Level III includes children who walk using a hand-held mobility device and use a wheelchair when traveling long distances. Children qualified to level IV use a wheelchair when transported. Children at level V are also transported in a wheelchair but are limited in their ability to maintain antigravity head and trunk postures $[5,6]$.

This standardized classification system allows the patient to be assigned to a suitable level of the gross motor performance [7]. The equivalent of the GMFCS scale in evaluating the functional ability of upper limbs is the MACS scale [8]. It is a subjective classification aimed at determining the functional level of the upper limbs by describing the child's use of hands to handle objects in daily activities [8]. The CFCS scale was developed in 2011 to classify CP children's communication skills [9]. It is used to determine the level and communication capabilities of patients with other people. This scale also includes five levels focused on activities (related to tasks and actions by an individual) and participation (involvement in a daily routine) in accordance with ICF and WHO standards [1]. The GMFCS scale also has a prognostic value because the child classified into one of the $\mathrm{V}$ levels in the future most often presents the motor skills described in this range [7].

The diagnosis of $\mathrm{CP}$ in the first years of life usually results in intensive multi-profile rehabilitation, planned and implemented by the members of the rehabilitation team and the parents of the child. The child's involvement in therapy should increase gradually throughout adolescence; unfortunately, the expectations of the child are not often taken into account. Our own long-term clinical observations indicate that in puberty and adolescence patients are usually reluctant to undertake rehabilitation efforts. This may be due to the lack of time for therapy caused by school workload. Adolescents with disabilities want to make their own decisions in regard to their daily lives and their future [10]. It is extremely important to know the opinions of the patients about their needs and expectations.

The main purpose of this study was to identify and present the opinions of CP patients on the possibility of independent functioning in adulthood within the context of their functional assessment. In addition, attempts were made to establish the relationship between functional level of mobility, self-service, communication, and the idea of independent living. The most common obstacles to independent living were analyzed.

\section{MATERIAL AND METHODS}

The study involved 29 patients. The study group consisted of 15-18 year old adolescents, mean age 16 years and 4 months; 8 children were 15 years old $(27.6 \%)$ and 7 children aged 16,17 and 18 years old (24.1\% each). Girls accounted for $51.7 \%$ of the respondents (15 girls) and boys $48.3 \%$ (14 boys). In the study group there were 10 patients with hemiplegia (34.5\%), 11 with diplegia (37.9\%), 6 with tetraplegia $(20.7 \%)$ and 2 with bilateral hemiplegia (6.9\%) (Fig. 1).

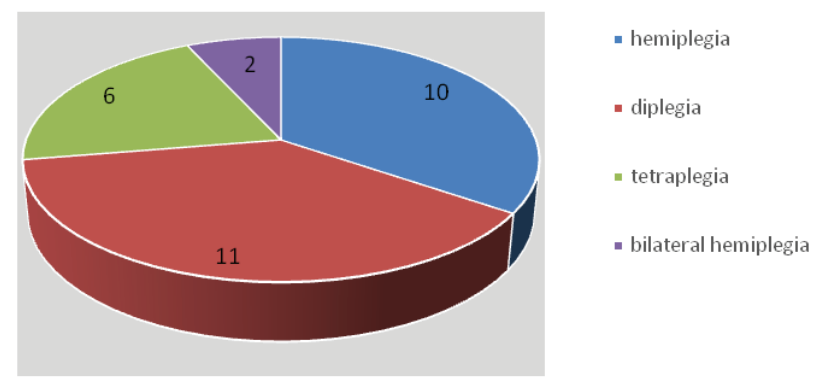

Fig. 1. Types of $\mathrm{CP}$ in the study group

Ryc. 1. Postaci MPD w grupie badanej

In the study population $31 \%$ of the patients $(n=9)$ are rural residents, the same number of patients lives in cities with over 50,000 residents and $37.9 \%(n=11)$ of patients live in cities with fewer than 50,000 inhabitants. In the study group normal mental development was found in 20 patients; a mild intellectual disability was reported in 7 patients, and a moderate one in 2 subjects. Due to the desire for personal (subjective) assessment of the functioning of CP patients at the threshold of adulthood, the researchers focused on the direct contact with the patient, excluding the impact of third parties. The inclusion criteria to the study included diagnosis of $\mathrm{CP}$, age between 15 and 18 years and possibility of direct communication with the patient. The exclusion criteria included deep mental impairment and lack of consent to participate in the study.

The research instruments were: functional assessment scales: GMFCS, MACS, CFCS, a patient's test card and questionnaire survey.

The study was conducted on patients with various levels of functioning. The structure of the study group was presented in terms of the gross motor function (GMFCS scale), the manual ability (MACS scale) and effectiveness of communication (CFCS scale) - Fig. 2.

In order to analyse the influence of the patients' functional state on their subjective assessment of their independence and how they perceive their daily challenges, the respondents were divided into three groups. The GMFCS scale was the leading criterion for the division whereas the MACS and CFCS scales were considered secondary. The first group included 10 patients with the highest level of functioning who reached Level I or II in the GMFCS, it is worth noting that the patients classified at a GMFCS level II were also classified at a MACS and/or CFCS level I. The second group included 7 patients with a lower level of functioning who reached Level III in the 


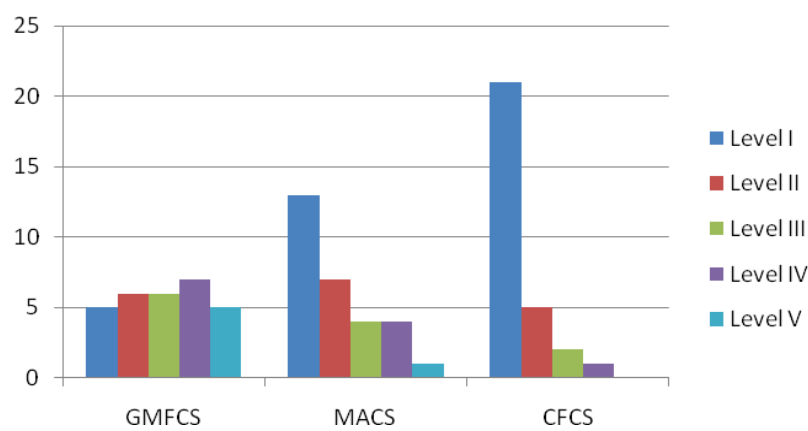

Fig. 2. Structure of the study group in terms of functional scales: GMFCS (Gross Motor Function Classification System), MACS (Manual Ability Classification System), CFCS (Communication Function Classification System); description of scales in the text

Ryc. 2. Struktura grupy badanej pod względem skal funkcjonalnych: GMFCS, MACS, CFCS (opis skal w tekście)

GMFCS and those who were classified at a GMFCS, MACS and CFCS level II. The third group included 12 patients classified as a GMFCS level IV or V whose level classification in MACS and CFCS varied. Further analysis of the results was based on the three groups described.

The Patient Test Card contained basic information about the type of disability associated with CP. It was based on the analysis of medical records and patient examination. Type of muscle tone disorders and localization of paresis, coexisting permanent dysfunction of the locomotor system with particular emphasis on the spine scoliosis and hip joints condition were entered to the card. The results of the functional assessment according to the aforementioned scales were included in the patient's examination card.

The questionnaire was addressed directly to the patients but with the possibility of filling it out by their parents or guardians. Questions in the survey questionnaire were formulated in a simple and unambiguous manner focusing on closed questions, however, leaving the opportunity to create their own answers. The questions included in the survey concerned the opinion of the respondents on the impact of their disability on their daily functioning and independence; they also addressed issues of the difficulties and obstacles in their adulthood.

The results were analyzed statistically. Correlations between continuous variables were determined using Spearman's rank correlation test. The results with a $p<0.05$ were considered statistically significant. All statistical analyses were done using Statistica ver. 9.0 (StatSoft Inc., Tulsa, OK 74104, USA).

\section{RESULIS}

Disability vs. functioning in everyday life: In the first group - the most functional $(\mathrm{n}=10)$ - half of the respondents declared that disability had a significant impact on their functioning. In the second group - less functional $(n=7)$ - fewer than half of the patients $(n=3)$ claimed that disability signifi-

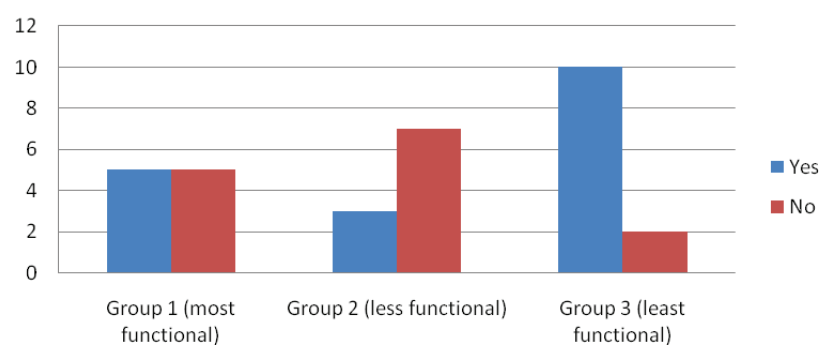

Fig. 3. Impact of disability on functioning in everyday life depending on the functional level

Ryc. 3. Wpływ niepełnosprawności na funkcjonowanie w życiu codziennym w zależności od stanu funkcjonalnego.

cantly affected their functioning. A significant difference was visible in the case of the third group - the least functional. In this group 10 respondents claimed that disability significantly affected their functioning in everyday life (Fig. 3).

Independent existence: More than half of the surveyed patients with $\mathrm{CP}(\mathrm{n}=15)$ imagined independent life without the help of third parties. The detailed analysis including the division into 3 groups based on functional scales presents the following results: in the best functioning group $90 \%(n=9)$ of the respondents imagine independent existence. Only 1 person from this group cannot imagine such a situation. Out of 7 patients from the second group (less functioning) 5 can imagine an independent life. Out of 12 patients from the third group (the least functioning) only 2 subjects can imagine an independent life (Fig. 4).

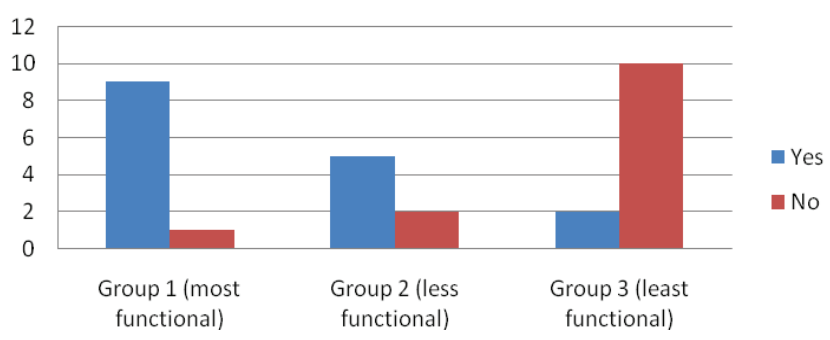

Fig. 4. The attitude of patients towards the possibility of independent existence depending on their level of functioning Ryc. 4. Stosunek pacjentów do możliwości samodzielnej egzystencji w zależności od poziomu funkcjonowania

Difficulties in everyday life: In a closed question regarding difficulties in everyday life, patients with $\mathrm{CP}$ had the following answers to choose from: mobility, personal hygiene, talking to people, learning, and lack of difficulty. It was a multiple choice question. The majority of the respondents $-75.7 \%(\mathrm{n}=22)$ - indicated mobility problems. 12 patients $(41.4 \%)$ chose difficulties with personal hygiene. Talking to people was difficult for $13.8 \%$ of patients $(\mathrm{n}=4)$. In contrast, learning was a problem for $34.5 \%$ $(n=10)$ of patients with CP. Only 2 patients $(6.9 \%)$ did not see any difficulties in everyday life related to their disability (Fig. 5). 
Tab. I. Obstacles to independent living

Tab. I. Przeszkody w niezależnym życiu

\begin{tabular}{cc}
\hline The biggest barrier in adult life & No of cases / All patients (Percentage of patients) \\
\hline Mobility difficulties & $12 / 29(41.4 \%)$ \\
\hline Job-finding problems & $7 / 29(24.1 \%)$ \\
\hline Architectural barriers & $6 / 29(20.7 \%)$ \\
\hline
\end{tabular}

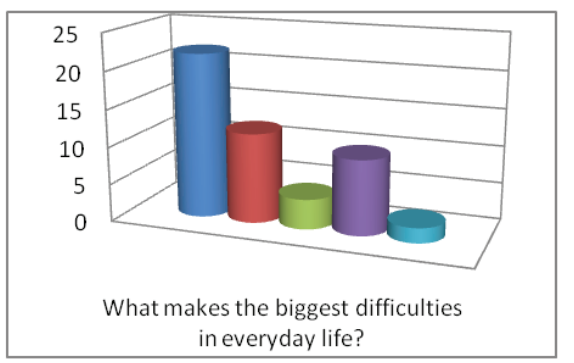

Mobility
- Personal
hygiene/grooming
Communication
Learning
Nothing

Fig. 5. Everyday activities that cause the greatest difficulty for patients with $\mathrm{CP}$

Ryc. 5. Czynności dnia codziennego sprawiające największe trudności pacjentom z MPD

Challenges in adult life: The subjects were asked what they thought may be the biggest obstacle to adult, independent living. The question was an open question. Most of them considered mobility to be the greatest challenge; this applied to $41.4 \%(n=12)$ of the surveyed patients with CP. Among obstacles to independent living 7 patients $(24.1 \%)$ indicated difficulties in finding a job, 6 subjects $(20.7 \%)$ indicated architectural barriers (Tab. I). Other, less mentioned obstacles were as follows: commuting, everyday activities, working on a computer, dependence on other people, driving a car, talking to people and slow development.

Intercurrent disorders: Most of the patients with $\mathrm{CP}$ had coexistent dysfunctions of: the musculoskeletal system (scoliosis - 69\%, hip dysplasia - 34.5\%), the organ of vision - $62 \%$, intellectual disability - $31 \%$, speech disorders $-27.6 \%$, damage to the hearing organ $-24.1 \%$. Epilepsy occurred in $55.2 \%$ of respondents. It was observed that the number of dysfunctions accompanying CP had a negative effect on the patients' functional level: the greater the number of intercurrent disorders, the smaller the possibility of independent living imagined by the subjects (Fig. 6).

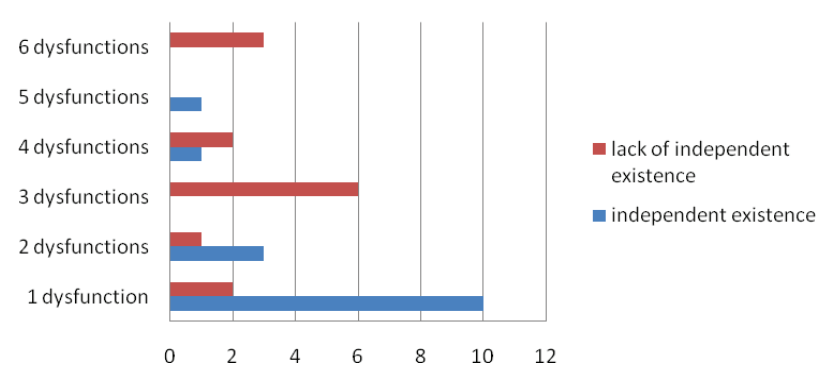

Fig. 6. Influence of the number of dysfunctions accompanying $\mathrm{CP}$ on the declaration of the possibility of independent existence

Ryc. 6. Wpływ ilości dysfunkcji towarzyszących MPD na deklarację możliwości samodzielnej egzystencji
More than half of the surveyed patients (16 out of 29: $55.2 \%$ ) plan to live independently. A negative correlation between GMFCS level and adult independence was observed (Fig. 7). Patients with hemiplegia are more independent than people suffering from diplegia or tetraplegia (Fig. 8). Only 34.5\% of CP patients (10 from 29) report disability as a cause of interpersonal problems.

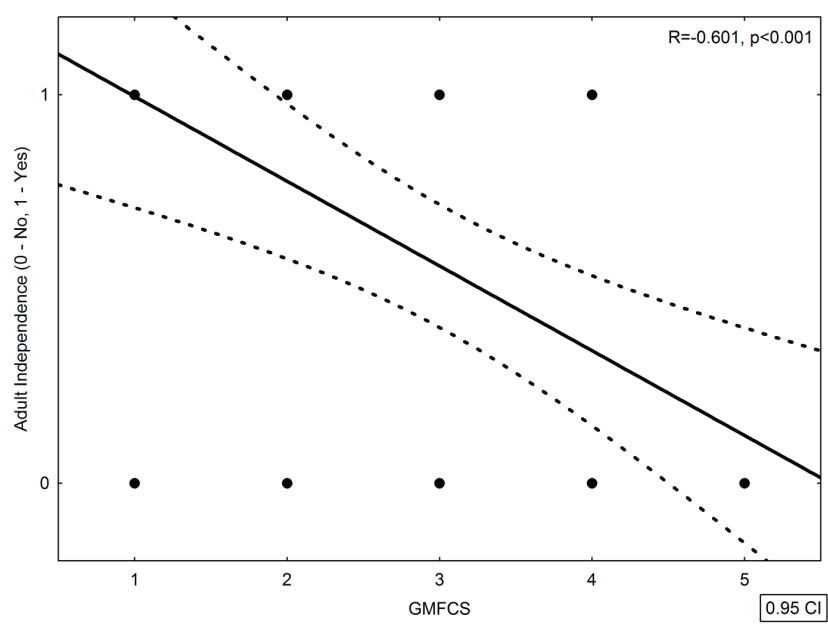

Fig. 7. Correlation between the level of GMFCS and adult independence

Ryc, 7. Korelacje pomiędzy poziomem funkcjonalnym GMFCS a niezależnością w życiu dorosłym

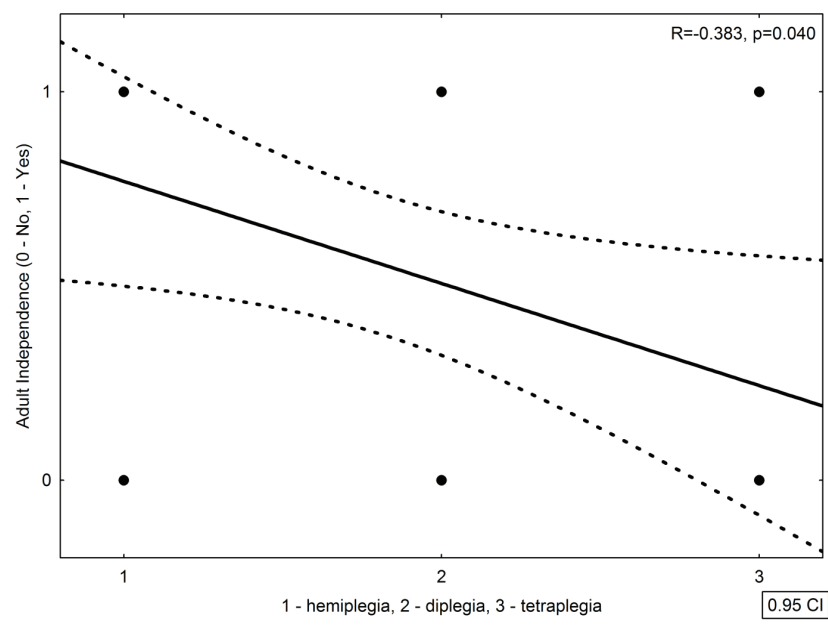

Fig. 8. Correlation between the type of paresis in CP patient and adult independence

Ryc. 8. Korelacje pomiędzy postacią MPD a niezależnością w życiu dorostym 


\section{DISCUSSION}

The opinion of CP patients entering adulthood regarding their perception of the future is very important. For this purpose, a preliminary review of Polish and foreign literature (Google Scholar, Pubmed) was performed with the keywords: cerebral palsy, independence, functional assessment, adolescents. There can be found in Polish literature the articles describing the problems of maturing adolescents with CP and single items about the quality of their life $[11,12]$, while articles regarding their life expectations as independent adults were not found. Articles analyzing participation of young adults with CP in everyday life can be found in foreign literature which is associated with an earlier implementation of the concept of the ICF than in Poland [13-15]. However, studies on the relationship between functional condition of adolescents with $\mathrm{CP}$ and their expectations for adult life were not found.

We know from our own clinical observations that congenital abnormalities disturb the development of the person from the very beginning and the process of coping with such a life is more difficult than in the case of acquired disability. People who are directly involved in the care of young CP patients can sometimes be the biggest obstacle to their progress. It is often helpful to have a conversation with the patient's family about the necessity to limit their care so that they can adapt to independent living to the extent allowed by their functional state. Older patients should decide for themselves what activities they want to participate in because they know their limitations and their needs the best. Many patients entering adult life experience for the first time negative factors that worsen their functional state. Also a new environment raises their fear and anxiety. Support from this environment should be provided so as to make them independent of home and family. Young people fear being rejected but mutual acceptance can pave the way for self-reliance $[10,16]$. In our study though, nearly twothird of respondents do not consider it a problem.

Adults with CP often experience an environmental rejection, mainly due to lack of knowledge about their disability and dysfunction. Most children and adolescents create an image of themselves as subordinate to the needs of other people. This is because they are usually the "recipients" of environmental influences (parents, professionals, peers), and less often they are donors or initiators of activities $[11,16]$.

Respondents emphasized concerns about adult autonomy in the area of mobility and architectural barriers. The latter posed a major challenge to self-mobility within the home and commuting to school, college or work. In our own observations, CP adolescents, despite their high functional efficiency, often need help from third parties. In our study, the problem was reported by every fifth patient. It is worth pointing out that more and more CP adults break the stereotype of a person with a disability as a person dependent on others, progressing well in life, being successful and active in society. This requires a tremendous effort from them in overcoming the internal barriers, such as physical and mental ones, as much as external barriers, such as social and cultural ones [10].
The problems of adolescents with $\mathrm{CP}$ in terms of their activity and participation in the context of the ICF concept are widely described in the foreign literature. Livingston et al. [18] presented a survey of Canadian youth with CP aged between 12.9 and 19.8 years, suggesting that the most common problems were active leisure (57\%), mobility (55\%), school attendance (48\%) and socialization (44\%). Sharp et al. [19] in their studies on the development of adolescents point to the significant impact of environmental factors on the identity development and on the acquisition of diverse skills. School, home, and community are the main contexts of activity in which learning adolescent usually participate [20]. These aspects are very important in a perspective formation by adolescent youth with disabilities who plan to live independently according to their functional state. A study conducted by Dussen et al. [21] in the group of 134 young adults shows that $30 \%$ lived with their parents, $12.5 \%$ with a partner and $32 \%$ independently. In this study, $55.2 \%$ of the respondents planned independence in adulthood, so the results confirm our data.

In our study, the most common obstacles to independent living were motility difficulties (41.4\%) due to disorder but also as a result of lack of accessibility (20.7\%). This problem is reflected both in Polish and foreign literature $[16,18,22]$. Young people have also reported concerns about finding a job (24.1\%), but the results are difficult to compare because they express fear of the future rather than lack of work. However, this is a much smaller percentage in relation to the CBOS report of 2017 on the assessment of the labor market and a sense of unemployment threat, where $35 \%$ of respondents had concerns about job opportunities [23].

The presented study on a small group of Polish adolescents with $\mathrm{CP}$ is an attempt to understand their expectations in adult life depending on their functional state. Although the social conditions in different countries and access to medical care vary, the expectations of young people are similar. The results showed that most $\mathrm{CP}$ adolescents have an idea of independent living and they try to achieve it with little or no help from third parties, especially if a higher level of functioning is possible. The presented research should be treated as a preliminary one, laying the groundwork for a detailed analysis of the expectations of Polish adolescents entering the adult age.

In conclusion, the level of functioning of patients with $\mathrm{CP}$ affects their perception of independent living. Patients with a lower grade of GMFCS (level I and II) and patients with hemiplegia are more likely to achieve independence in adulthood than those with a high grade of GMFCS (level IV and V) and with di- or tetraplegia.

\section{REFERENCES}

[1] World Health Organization. International classification of functioning, disability and health. Geneva, Switzerland: World Health Organisation. 2001.

[2] Rosenbaum P., Stewart D.: The World Health Organization International Classification of Functioning, Disability, and Health: a model to guide clinical thinking, practice and research in the field of cerebral palsy. Semin Pediatr Neurol 2004; 11: 5-10.

[3] Bax M., Goldstein M., Rosenbaum P., et al.: Proposed definition and classification of cerebral palsy, April 2005. Dev Med Child Neurol 2005; 47: 571-576. 
[4] Rosenbaum P., Paneth N., Leviton A., et al.: A report: The definition and classification of cerebral palsy April 2006. Dev Med Child Neurol Suppl 2007; 109: 8-14.

[5] Rosenbaum P., Walter S., Hanna S., et al.: Prognosis for gross motor function in cerebral palsy: creation of motor development curves. JAMA 2002; 288: 1357-1363.

[6] Palisano R., Cameron D., Rosenbaum P., et al.: Stability of the Gross Motor Function Classification. Dev Med Child Neurol 2006; 48: 424-428.

[7] Gajewska E.: The new definitions and functional scales used in children with cerebral palsy. Neurol Dziec 2009; 18: 67-71.

[8] Eliasson A., Krumlinde-Sundholm L., Rösblad B., et al.: The Manual Ability Classification System (MACS) for children with cerebral palsy: scale development and evidence of validity and reliability. Dev Med Child Neurol 2006; 48: 549-554.

[9] Hidecker M., Paneth N., Rosenbaum P., et al.: Developing and validating the Communication Function Classification System (CFCS) for individuals with cerebral palsy. Dev Med Child Neurol 2011; 53: 704-710.

[10] Dąbrowska-Zimakowska A.: Sense of coherence and coping in young adults with cerebral palsy. Advances in Rehabilitation 2015; 29: 5-12.

[11] Michalska A., Wendorff J., Boksa E., et al.: Quality of life of children and young people with cerebral palsy and intellectual disability. Selected clinical conditionings. Neurol Dziec 2012; 43: 39-48.

[12] Topór E., Kułak W.: Quality of life children with cerebral palsy. Neurol Dziec 2010; 19: 61-65.

[13] Frisch D., Msall M.: Health, functioning, and participation of adolescents and adults with cerebral palsy: a review of outcomes research. Dev Disabil Res Rev 2013; 18: 84-94.
[14] Donkervoort M., Roebroeck M., Wiegerink D., et al.: Determinants of functioning of adolescents and young adults with cerebral palsy. Disabil Rehabil 2007; 29: 453-463.

[15] Østensjø S., Bjorbækmo W., Carlberg E., et al.: Assessment of everyday functioning in young children with disabilities: An ICF-based analysis of concepts and content of the Pediatric Evaluation of Disability Inventory (PEDI). Disabil Rehabil 2006; 28: 489-504.

[16] Sendecka E., Wiśniewska E., Krajewska-Kułak E., et al.: Social functioning of family with disabled child. Neurol Dziec 2010; 19: 67-73.

[17] Lewandowska A., Zajchowska J., Iwaniszyn J., et al.: Functioning of the family of a child suffering from cerebral palsy. J Pre-Clin Clin Res 2012; 6: 50-53.

[18] Livingston M., Stewart D., Rosenbaum P., et al.: Exploring issues of participation among adolescents with cerebral palsy: What's important to them? Phys Occup Ther Pediatr 2011; 31: 275-287.

[19] Sharp E., Coatsworth J., Darling N., et al.: Gender differences in the selfdefining activities and identity experiences of adolescents and emerging adults. J Adolesc 2007; 30: 251-296

[20] Simons D.: Adolescent development. In: Human development and performance throughout the lifespan. Cronin A. \& Mandich M.(Eds). Clifton Park, NY: Thomson Delmar Learning, 215-245; 2005.

[21] Dussen L., Nieuwstraten W., Roebroeck M., et al.: Functional level of young adults with cerebral palsy. Clin Rehabil 2001; 15: 84-91.

[22] Lawlor K., Mihaylov S., Welsh B., et al.: A qualitative study of the physical, social and attitudinal environments influencing the participation of children with cerebral palsy in northeast England. Pediatr Rehabil 2006; 9: 219-228.

[23] http://www.cbos.pl/SPISKOM.POL/2017/K_035_17.PDF 